Teaching \& Learning (2011) 6(1), 53-61

\title{
Stealing the Age of Innocence: A Critique of the Commodification of Children's Culture Through an Analysis of NeoPets
}

\author{
RHON TERUELLE \\ University of Toronto Doctoral Student
}

\begin{abstract}
This paper functions as both a reflection on the promotion of digital technologies to children, and as an investigation into the commodification of children's culture, using NeoPets as the primary focus of the exploration. Specifically, the development of the child/user to targeted consumer is analyzed, with a focus on website's marketing techniques. While NeoPets provides a virtual "fun" world that caters to children, another reason to ponder the significance of this on-line community is to better understand how its technological and marketing savvy function as exploitive tools. Moreover, it is imperative to address the lack of policies, in Canada and the United States, in order to affect eventual progressive changes in both countries.
\end{abstract}

\section{Introduction}

Billed as the "greatest Virtual Pet Site on the Internet" and boasting well over 70 million virtual pet owners, NeoPets has metamorphosed into a worldwide phenomenon. Found on the World Wide Web under www.NeoPets.com, the NeoPets website provides a space for a growing on-line community of virtual pet owners. NeoPets are virtual creatures that live in the land of “Neopia,” a world that features a bank, a hospital, a food shop, a book shop, a magic shop, an art centre, a school, and a pharmacy. The site also contains a plethora of online games that are designed to award players with currency in the form of "NeoPoints." Once earned, NeoPoints can be used to purchase food, items and accessories for one's pet. Evidencing the allure of the site, the vibrant homepage promotes free membership to a fantastic world of play. However, the corporation that currently owns NeoPets purposefully exploits its members, ideologically, under the guise of providing leisure activities, while simultaneously promoting consumerism. This paper will address the commodification of children's culture through an analysis of NeoPets. Specifically, I will critique strategic marketing ploys implemented by multi-million dollar corporations that explicitly target children. Moreover, I will also reflect on some of the complexities that surround the protection of children from corporate exploitation. 


\section{Discussion}

Firstly, before exploring the commodification of children's culture, it is imperative to define the term “commodity.” According to Marx (1977), a commodity is simply anything that can be bought or sold which satisfies a human need and possesses both a use-value and an exchange-value (p. 125). In short, a commodity's use-value is the usefulness of the thing due to its physical body: a qualitative value. Moreover, the use-value becomes relevant only when the commodity is being consumed. Exchange-value, on the other hand, "appears to be something accidental and purely relative, and consequently an intrinsic value” (Marx, 1977, p. 126). The exchange-value also differs from the use-value because it takes into account what a commodity can be exchanged for, that is, its quantitative aspect. An article by Oser and Klassen (2005) reveals that in May of 2005, MTV Networks, a division of media conglomerate Viacom, bought NeoPets for \$160 million dollars (p. 52). Since NeoPets clearly displays both a use-value (for children’s play) and an exchange-value (sold for profit), it can definitively be considered a commodity. Fundamentally, capitalism transforms most everything into a commodity, and as evidenced by this particular transaction, children's culture has been included in this commodification.

NeoPets appears to have a dual purpose. It provides leisure activities, while maximizing profits through the promotion of consumption. Created by two British university students, Adam Powell and Donna Williams, NeoPets was launched in November 1999, and was initially conceived as a relatively safe world of make-believe in which children can play. Communication professors Shade and Grimes (2008) explain the website’s function:

The premise is that children and youth create or adopt a pet that then needs to be taken care of. Acquisition of currency (called "NeoPoints", which are gained by playing various games, exchanging or selling items, filling out marketing surveys and questionnaires, and entering contests and games of chance) allows for the purchase of food, toys and other virtual consumer products. (p. 2)

Therefore, NeoPets can be rationalized as a virtual community that allows children to acquire a multitude of life-skills, and if they desire, to also practice scholastic-related activities through play in a fantastic realm. 
Despite being underpinned by capitalism, NeoPets does exhibit some positive attributes. There have been documented cases of Australian grade school teachers using the site to teach their students basic economics. Moreover, the website also helps children develop a strong sense of community through their interactions with the other members. NeoPets, according to Shade and Grimes (2008), “is a vibrant online community where members interact with each other, construct projects, play games and contests, and engage in entertainment activities related to current popular culture” (p. 4). As opposed to other participatory activities, it can be argued that members of NeoPets community continually engage in educational exercises, while playing on the website. As well, positive themes such as sociability, entertainment, exploration, and creation are promoted by NeoPets. Presumably, due to continual changes, updates, and many new events within its "nearly unlimited number of pages and spaces to explore," NeoPets is able to preserve membership interest by maintaining its great entertainment value (Shade \& Grimes, 2008, p. 6).

Although it obviously exhibits several positive characteristics, NeoPets' negative aspects cannot, and should not, be discounted. Numerous critics agree that children are highly impressionable. When visiting the world of Neopia, all members, including a multitude of impressionable children, are constantly bombarded with an ingenious form of advertising. In response to advertising targeting children, the article entitled "Special Issues for Young Children” (n.d.) warns parents of the effects of materialism: “Children’s identities shouldn’t be defined by their consumer habits; yet that is the main way they see themselves reflected in the media - as consumers, and advertisers are targeting younger and younger children with this message” (Effects of materialism section, para. 2). As opposed to teaching children positive morals, values, and ideals, materialism alone is instead encouraged by advertisers. Banet-Weiser (2007) argues that this type of situation is indicative of the contemporary moment, as "the market is understood as constitutive of citizenship through the interpellation of children, and this interpellation of children is about making subjects for the market” (p. 7). Similarly, Giroux (1999) considers the rise of corporate culture as having contributed to "children relinquishing their roles as critical subjects for the passive role of consuming subjects” (p. 23). Additionally, Jenkins (1998) posits that children's social and cultural development is impacted by “adult agendas and expectations, at least on the site of production and often at the moment of reception” (p. 26). If Jenkins' (1998) statement is true, then those (adults) in charge of NeoPets are implicated in a problematic situation, whereby children identify themselves primarily as 
consumer citizens, who practice what Veblen (1965) refers to as “conspicuous consumption,” and who have minimal interest in more important issues, arguably, such as social responsibility (p. 148).

As a financially successful enterprise, NeoPets has effectively implemented "immersive advertising” as its main form of revenue generation. Immersive advertising, a term that has since been trademarked by NeoPets, is a marketing strategy that allows advertisers to integrate their products and identifiable characters throughout the site. Similar to product placement techniques found in movies and television programs, companies utilize omnipresent images to reinforce brand awareness. Shade and Grimes (2008) refer to NeoPets as "exemplary of trends in the creation of lifelong branded entertainment for children and youth” (p. 2). In fact, because of the site’s great success, food manufacturers and multi-national entertainment conglomerates have been quick to participate in the growing phenomenon.

A quick tour through Neopia reveals that several Disney characters, as well as personalities associated with Mattel, MGM, McDonald's, Corus Entertainment, and Kraft, are noticeable during game play. Oser and Klassen (2005) illustrate the immersive advertising found on the website with the following:

The site's ad strategy has been to integrate advertisers' brands into the content with "immersive advertising." So, for example, Disney film trailers are shown in the Disney Theatre when the user clicks to see them, a McDonald's area features a stamp-collection treasure hunt and a game sponsored by Procter \& Gamble's Crest challenges the player to brush a Grarrl pet's teeth with a new electric toothbrush. (p. 52)

Through immersive advertising, corporations are able to interact with children on two levels: the conscious and the subconscious. Although highly questionable, this form of advertising has yet to be regulated and is an accepted (and increasingly preferred) practice by a growing number of marketers.

Through their mandatory membership process, NeoPets is able to target specific demographics from the information they obtain. Further, a study performed indicates that brand awareness increased dramatically as a result of immersive advertising. Oser and Klassen (2005) state, "When online survey firm Dynamic Logic followed up NeoPets' tracking for a videogame-company promotion, it found aided brand awareness of 62\%, vs. 3\% for the market norm. 
Purchase intent was 13\%, vs. 2\% for the market norm” (p. 52). These results are staggering and display the efficiency of immersive advertising, as its impact on children is both manifest and measurable. Consequently, as active participants on the website, children, as willing consumers of the entertainment that is offered, thus become “exploited by commercial interests” during play (Shade \& Grimes, 2008, p. 18).

Noticeably, the presence of Disney is quite pronounced in the Neopian realm. For years, multi-million dollar conglomerates such as McDonald's, Burger King, Pizza Hut, Disney, and OshKosh, have purposefully marketed towards children. Shields (2005) addresses the issue of immersive advertising with the following:

Of course, with any kids-directed marketing, there are detractors. Some experts say the practice of designing branded games for kids is even more dangerous than directly selling to them, since kids can't distinguish what is and is not marketing. Harvard Medical School instructor Susan Linn called the mix of content and advertising to kids 'an abuse,' adding that NeoPets is 'really troubling.' (p. 4)

According to Shields (2005), many critics believe that immersive advertising is problematic, because it blurs the lines between marketing and leisure. Therefore, through this clever marketing strategy, identifiable characters and products become ubiquitous, and remain unobtrusive in the land of Neopia, seemingly integrated in a naturalized fashion. While playing NeoPets, children simultaneously participate in consumer citizenship.

Several theorists, including Ruskin (1999), argue against the use of advertisements that directly target children. In his article entitled "Why They Whine: How Corporations Prey on Our Children,” Ruskin (1999) demonstrates the apparent shift in how children are now viewed by corporations. Instead of being considered as “vulnerable beings to be nurtured,” marketers only see children through an “economic lens” (Ruskin, 1999, p. 2). Although advertisements targeting children have been in existence for a number of years, Ruskin’s (1999) article reveals that today's corporations now include personnel whose jobs entail “molding” children into life-long brand-loyal consumers in order to take advantage of the children’s market: a \$24.4 billion “primary” market and a \$300 million “influence” market. The primary market is described as "what kids directly control and spend" and the influence market is referred to as "the amount of parental spending that children can directly or indirectly influence” (Ruskin, 1999, p. 2). Wayne Chilicki (as cited in Ruskin, 1999), a General Mills executive, explains his company’s rationale: 
"When it comes to targeting kid consumers, we at General Mills follow the Proctor \& Gamble model of 'cradle to grave.' We believe in getting them early and having them for life” (pp. 2-3). Thus, ultimately, executives at General Mills ascribe to the importance of targeting children with advertisements in the hopes of fostering a lifetime of brand loyalty. Not only are General Mills products located throughout Neopia, but "Blue Kougra,” a character created by NeoPets, is imprinted on the front of boxes of NeoPets Islandberry Crunch, a General Mills cereal that was released to the market in the early part of 2006. This particular example characterizes not only NeoPets' growing relationship with General Mills, but it also illustrates how the website's data mining results in the development and production of concrete products, which are then sold to its members.

Essentially, as a response to a number of corporate marketing strategies, European countries such as Greece, Sweden, and Norway have instituted policies that ban television advertising directed at children. Locally, Québec has a similar policy. In Québec, it is illegal to advertise directly to children under the age of thirteen. According to the article entitled "Regulations under the Québec Consumer Protection Act concerning advertising directed to children” (n.d.), restrictions include the following: the use of themes pertaining to fantasy, magic, mystery, suspense and adventure; the inappropriate use of children, the use of childish voices, heroes, fantastic or eccentric creatures, and the use of animals; the use of music that is particularly attractive to children. Although these measures have been effective in reducing corporate exploitation of children in the province of Québec, a similar regulation seems almost impossible to enforce in a virtual space.

Since its parent company, Viacom, is based in America, it seems highly improbable to effectively monitor and regulate the type of advertising that can be found at the NeoPets site. As it stands, current American laws and regulations that are specifically designed to protect children, only deal with limiting sexual and violent content. The United States of America does not censor children's advertisements. In fact, recent Republican-mandated American policies have allowed for the deregulation of institutions, and the furthering of neoliberal ideals that advocate consumerism, while subjecting its citizens to the power of the market. The Media Awareness Network in the article "Special Issues for Young Children” (n.d.), claims that young children are “especially vulnerable to misleading advertising and don't begin to understand that advertisements are not always true until they are eight” (Developmental concerns section, para. 
3). Therefore, as the Media Awareness Network suggests, it is imperative that steps be taken in order to monitor and control the amount, and the type of advertisements to which impressionable younger children are exposed.

Similar to the Media Awareness Network, theorist Postman (1982;1994) likewise desires to protect children. However, Postman (1982;1994) takes the issue one step further by proposing that the media, clothing, games, adult expectations, and Western culture in general, are all complicit and have contributed to the disappearance of childhood. Commenting on child's play, Postman (1982;1994) posits the following: "What we have here is the emergence of the idea that play is not to be done for the sake of doing it but for some external purpose, such as renown, money, physical conditioning, upward mobility, national pride” (p. 131). Although it is sometimes difficult to ascertain whether or not a child has ulterior motives for playing, what is evident is that play in Neopia is invariably entangled in consumerism. That being said, one of Postman's (1982;1994) questions resonates even louder: "Why should anyone wish to deny children the freedom, informality, and joy of spontaneous play?” (p. 131).

Whereas Postman (1982;1994) laments the loss of childhood innocence, many other critics argue against the presence of said innocence, and instead support the existence of childhood agency. Jenkins (1998) gestures towards Postman’s (1982;1994) mythology: “The innocent child is a myth, in Roland Barthes' sense of the word, a figure that transforms culture into nature” (p. 15). However, he also concedes that adults help shape children's culture: "Children are subject to powerful institutions that ascribe meanings onto their minds and bodies in order to maintain social control” (Jenkins, 1998, p. 26). In short, although Jenkins (1998) repudiates the idea of the innocent child, he also recognizes the obvious impact of adult-created institutions, despite children's agency. Returning to NeoPets, whilst younger members display agency through their active participation as empowered consumer citizens, the site's influence on these children is both apparent and well-documented.

Another critic who rejects childhood innocence, Seiter (1993), also advocates consumptive practices. She argues that "all members of modern developed societies depend heavily on commodity consumption, not just for survival but for participation - inclusion - in social networks" (Seiter, 1993, p. 3). Further, she claims that shielding children from consumption is "a middle-class delusion - though one often propogated by child experts" (Seiter, 1993, p. 3). While it is unrealistic to think that consumption can be completely circumvented, it 
is not a bad thing to try to protect children from harm. In the case of NeoPets and immersive advertising, it is completely understandable and important to safeguard children, especially the younger ones, from unethical marketing practices.

\section{Conclusion}

Although I do not agree with Postman’s (1982;1994) conception of the innocent child, and instead accept the actuality of childhood agency, I do believe that a change in policy focused on advertisements that target children needs to be revisited. Mainly due to the rise of neoliberal tendencies in the West, commodification has extended to children's culture. The increased commercialization of children's web-based content continues to be a problem, yet multi-million dollar industries are unlikely to change their business practices, as profits remain privileged over societal concerns. As evidenced by NeoPets, even a seemingly idyllic virtual community specifically designed for children is undermined by the forces of capital. Essentially, since the state remains uncommitted to providing protection for children from corporate exploitation, parents, guardians, and teachers ultimately carry the responsibility for limiting exposure, and education. They need to be cognizant of what children are being exposed to, and react accordingly. For example, further education about marketing strategies may provide children with some added awareness, which, in turn, would allow them to effectively respond to innovative corporate schemes, such as immersive advertising. As well, limiting the amount of time spent on any website could negate, or at least reduce, the power of advertising. However, despite these preventative measures, much larger questions remain: What are the possible ramifications of allowing marketers unmitigated access to (impressionable) children? Is it a societal responsibility to protect children from commercial exploitation? Should we, collectively, attempt to reduce consumer citizenship while simultaneously lauding childhood agency? Is there a way to limit children's consumer tendencies in an increasingly neoliberal globalized world? All questions that demand answers for the sake of, not only the children, but us all!

\section{References}

Banet-Weiser, S. (2007). Kids rule! Nickelodeon and consumer citizenship. Durham: Duke University Press.

Giroux, H. A. (1999). The mouse that roared: Disney and the end of innocence. Lanham: Rowman \& Littlefield. 
Jenkins, H. (Ed.). (1998). The children's culture reader. New York: New York University Press.

Marx, K. (1977). Capital: A critique of political economy. (B. Fowkes, Trans.). New York: Vintage Books.

Oser, K. \& Klassen, A. (2005). MTV Networks’ pet project likely to pay off. Advertising Age, 76(6), 52.

Postman, N. (1994). The disappearance of childhood. New York: Vintage. (Original work published 1982).

"Regulations under the Quebec Consumer Protection Act concerning advertising directed to children.” (n.d.). Media Awareness Network. Retrieved from http://www.media-awareness.ca/english/resources/legislation/canadian_law/ provincial/quebec/consumer_protection_actqc.cfm

Ruskin, G. (1999, November/December). "Why they whine: How corporations prey on our children.” Mothering, 97, 41-50.

Seiter, E. (1993). Sold separately: Children and parents in consumer culture. New Brunswick, NJ: Rutgers.

Shade, L. R., \& Grimes, S. M. (2005). Neopian economics of play: Children’s cyberpets and online communities as immersive advertising in NeoPets.com. International Journal of Media and Cultural Politics, 1(2), 181-198.

Shields, M. (2005). Surfing lessons. MediaWeek, 15(28), 4.

"Special issues for young children." (n.d.). Media Awareness Network. Retrieved from http://www.media-awareness.ca/english/parents/marketing/ issues_kids_marketing.cfm

Veblen, T. (1965). The portable Veblen M. Lerner, (Ed.). New York: Viking Penguin. 